International Journal of Canadian Studies

Revue internationale d'études canadiennes
INTERNATIONAL JOURNAL OF CANADIAN STUDIES REVUE INTERNATIONALF D'ETUDES CANADIENNES

\title{
A Review of Daniel Coleman's White Civility: The Literary Project of English Canada
}

\section{Jill Didur}

Numéro 38, 2008

Borders, Migrations and Managing Diversity: New Mappings

Frontières, migrations et gestion de la diversité : nouvelles

cartographies

URI : https://id.erudit.org/iderudit/040812ar

DOI : https://doi.org/10.7202/040812ar

Aller au sommaire du numéro

Éditeur(s)

Conseil international d'études canadiennes

ISSN

1180-3991 (imprimé)

1923-5291 (numérique)

Découvrir la revue

Citer cet article

Didur, J. (2008). A Review of Daniel Coleman's White Civility: The Literary Project of English Canada. International Journal of Canadian Studies / Revue internationale d'études canadiennes, (38), 191-195.

https://doi.org/10.7202/040812ar d'utilisation que vous pouvez consulter en ligne. 


\section{Jill Didur}

\section{A Review of Daniel Coleman's White Civility: The Literary Project of English Canada}

A recent front-page story in The Globe and Mail ran under the headline "How Canadian Are You?" The story reports that a study by University of Toronto sociologist Jeffrey Reitz found that "[v]isible-minority immigrants are slower to integrate into Canadian society than their white, European counterparts, and feel less Canadian, suggesting that multiculturalism doesn't work as well for non-whites" (Jiménez, 2007, p. A1). While Professor Reitz reached his conclusions through the study of statistical data gathered in 2002, Daniel Coleman's White Civility: The Literary Project of English Canada suggests the roots of this sense of exclusion have a long history that is evident through the study of popular literature written and published in Canada between 1850 and 1950. As the title of Coleman's book suggests, he examines how "White normativity" (Coleman, 2006, p. 3) was produced and represented by early Canadian literature and reflects common cultural conventions associated with colonial and settler culture in the nineteenth and early twentieth centuries.

Coleman's study looks at the history of the "construction of White, English Canadian privilege" (Coleman, 2006, p. 3) and asks,

How did this normative concept of (English) Canadianness come to be established in the first place? What are its elements? What is its genealogy? And how might an understanding of the process of its establishment enable twenty-first-century Canadians to anticipate and resist its continuous coercive power? (Coleman, 2006, pp. 4-5)

Coleman takes on the tricky task of making visible the assumptions associated with "Whiteness" in Canada - assumptions so pervasive they both determine and at the same time remain transparent mediators of Canadians' sense of national identity. His study tracks the genealogy of "Whiteness" in Canada through popular Canadian fiction, which Coleman argues is one of the best places to examine the complexities of nationalist identity. Coleman looks at popular literature published in Canada over approximately one hundred years in an attempt to map out 
where the norm of what he calls White civility is established and how it is reproduced and contested over time. The choice of focusing on popular rather than official texts allows Coleman to consider writing "produced not only by those who securely hold the reins of power but also by those who are lobbying for power" (Coleman, 2006, p. 35). The analysis in White Civility considers how popular literature is used by "educated elites and reform-oriented lobby groups" to create fantasies of national character and "shape popular views in advance of the pedagogies of the state" (Coleman, 2006, p. 36, original emphasis).

The White "fictive ethnicity" (Balibar in Coleman, 2006, p. 7) that has attached itself to the Canadian national context is largely explained by Coleman's analysis of these texts. In the process of reviewing this slice of Canadian popular culture, Coleman concludes, "White Canadian culture is obsessed and organized by its obsession, with the problem of its own civility" (Coleman, 2006, p. 5). Civility in this popular fiction denotes "the temporal concept of progress and the moral-ethical ideal of orderliness...demonstrated by cultivated, polite behaviour (most commonly modelled on the figure of the bourgeois gentleman), which, in turn, made these concepts fundamental to the production and education of the individual citizen" (Coleman, 2006 p.10). This "isochronous" (Coleman, 2006, p. 12) understanding of temporality privileges European modernity over other forms of governance (considered "less advanced") and places societies and individuals whose outlook or conduct does not conform to this world view as in need of education and "improvement." Race or Whiteness is tethered to notions of civility as part of what Coleman and other scholars have identified as its inherently ambivalent or contradictory structure: "[I]n the very period of the Enlightenment, when concepts of democratic rule, egalitarianism, and individual liberty were emerging as social ideals, there also arose the most nefarious and complex system the world has ever seen for classifying and stratifying humans into a hierarchy of racial types" (Coleman, 2006, p. 13). In the fiction Coleman discusses, "modern civility is [shown to be], paradoxically, a limited or constrained universality that tends to proliferate and striate not only external but also internal differences" (Coleman, 2006, p. 13). Coleman's readings of early. popular Canadian literature make visible a slippage between moral and racial criteria for determining one's relationship to civility when literary personas fail to assimilate to the norms associated with Whiteness.

"Canadianization" for European immigrants is determined by one's degree of assimilation to the so-called universal ideals represented by White civility. In Ralph Connor's The Foreigner, for example, Coleman examines how the civilization of a young male Ukrainian immigrant is contrasted with the unredeemable characters of "the Cossack zealot, the 
Jewish slumlord, and the "half-breed"' (Coleman, 2006, p. 180). Thus, in Connor's novel the young, rough-edged Catholic Ukrainian, Kalman, is represented as undergoing a process of masculine maturation when he rejects his father's Old-World values under the guidance of a Scottish Presbyterian missionary and an English ranch owner. Allegory and pedagogy are key concepts in Coleman's analysis of the construction of white civility in popular Canadian fiction of this era. Coleman limits his study to this early period as he argues that the Canadian literary culture "has not yet undergone the private-public, personal-political split" and "writers tend to figure the individual narrative as representative of national narrative, particularly by means of the growing-up story, whereby the youth's process of maturation represents young Canada's emergence onto the international stage of modern nations" (Coleman, 2006, p. 37). Allegory, for Coleman, is understood as "a tense rhetorical form because it compresses powerful and often contentiously political ideologies into a dense bundle in its effort to incorporate unassimilated phenomena into the formulations of the familiar and the known" (Coleman, 2006, p. 40). Its pedagogical implications are also more complicated than first assumed. The allegorical "lesson" that informs Canadian nationalism, according to Coleman, "never matches exactly in a tight, one-to-one correspondence the actions or performances of its tropic figures" (Coleman, 2006, p. 40). It is "the gap" between these two things, between the "pedagogical and the performative elements in national allegory" (Coleman, 2006, p. 40), a gap that has motivated similar studies of postcolonial nationalism in our field (most notably, Bhabha's Nation and Narration), that White Civility sets out to map in the early Canadian context.

The four allegorical figures that organize the analysis in White Civility and that appear repeatedly in the popular texts with which Coleman is concerned include the Loyalist brother, the enterprising Scottish orphan, the muscular Christian, and the maturing colonial son. Each of these allegories represents a repetition of a specific aspect of the "official symbolic history of Canada" that obscures its supplement-what Coleman, following Slavoj Žižek, suggests is its "'spectral,' fantasmatic history" (Coleman, 2006, p. 28). This "undead" history includes, among other things, "[t]he denial of Indigenous presence in these lands, the disregard of pre-contact history, and the continuing suppression of First Peoples' claims to land and sovereignty" (Coleman, 2006, p. 29). "For Canadians" Coleman argues, "the performance of civility is a way to manage our traumatic history" (Coleman, 2006, p. 29). The four allegories are discussed in detail in the four main chapters of the book, each of which offers revealing insights into the underside of Canadian notions of "civility" or what Gauri Viswanathan has called "masks of conquest" (Viswanathan, 1989, p. 1): For example, chapter 2 offers a convincing analysis of how the spectre of fratricide between British colonials and selfish economic 
motives (i.e., the desire for property) are contained by an allegory of fraternity that rationalizes "brotherly brutality" (Coleman, 2006, p. 47). In these narratives, the civility of Loyalist characters is "demonstrated by their aligning themselves with vulnerable non-Whites" (Coleman, 2006, p. 47) such as Black and First Nations characters. Building on his previous work on masculinity (Masculine Migrations, 1998), Coleman goes on to explain that the "backward-looking" quality of this homosocial allegory (i.e. a "bachelor society cannot reproduce itself") is redeemed in the conclusion of most texts by the sudden recruitment of women and the substitution for the fraternal with a matrimonial allegorical twist (Coleman, 2006, pp. 47-48).

In chapter 3 Coleman discusses the allegory of "the enterprising Scottish orphan" whose story is reiterated in books such as Connor's The Man from Glengarry and the more familiar Barometer Rising by Hugh MacLennian. Coleman's analysis of this allegory offers insight into the invention of Canadian/British ethnicity, which is primarily an assimilation of Scottish ethnicity as constructed in the post-Unionist period in Britain and rerouted through early Canadian settler culture. The Canadian version of this story involves the ubiquitous narrative of the Scottish orphan who settles in Canada, adheres to a strict code of "moral and domestic improvement" (Coleman, 2006, p. 111) and eventually displaces both the indigenous figure as well as the elite English settler. This story of selflessness coupled with upwardly mobility comes to stand in for the idealized profile of the "English Canadian" citizen.

Perhaps the most important theoretical move Coleman makes in the book is to suggest that an attitude of "wry civility" (Coleman, 2006, p. 41) be substituted for the White civility that has inflected the production and reception of the popular literature and culture discussed in his book. As he provocatively asks, "What distinguishes a twenty-first-century project of civility such as mine from nineteenth- or early twentieth-century forms of civility such as the ones I examine and critique?" (Coleman, 2006, p. 41). An attitude of "wry civility" is Coleman's answer to the tendency of readers, critics, or citizens who identify with the concept of (white) civility to assume their values and culture represent a kind of universal or neutral conduct. Wry civility, for Coleman, involves the performance of "our selfconsciousness that we are implicated in the history of racism" and a call for critics of White civility to remain "ironically aware of the pretentiousness of the civility that we nonetheless aspire to, and also the pretentiousness in trying to be self-aware" (Coleman, 2006, p. 43). It is this productively paradoxical, deconstructive practice that informs much of the analysis and commentary in White Civility. The book's conclusion encourages readers to think beyond the edges of Coleman's study and examine the limits of some contemporary postcolonial and postmodern approaches 
to Canadian multicultural fiction that fail to acknowledge the critic's own implication in the interested production of knowledge. Rather than abandon the project of civility, Coleman calls on critics to acknowledge its "contaminated, compromised history" even while they affirm "that its basic elements as formulated in Canada-peace, order and good government-are worth having and maintaining" (Coleman, 2006, p. 239).

The stakes of Coleman's project are clearly and eloquently outlined throughout the book. What the Globe and Mail story mentioned above suggests is that despite the rhetoric of multiculturalism that informs popular and official representations of Canadian society, "whiteness still occupies the positions of normalcy and privilege in Canada, and anti-racist activity remains hamstrung until we begin to carry out the historical work that traces its genealogy" (Coleman, 2006, pp. 7-8). Daniel Coleman's White Civility represents a pivotal contribution to this larger project.

\section{Reference List}

Bhabha, Homi K. (1990). Nation and Narration. New York: Routledge.

Coleman, Daniel. (1998). Masculine Migrations: Reading the Postcolonial Male in

New Canadian Narratives. Toronto: University of Toronto Press.

Coleman, Daniel. (2006). White Civility: The Literary Project of English Canada.

Toronto: University of Toronto Press.

Conner, Ralph. (1901). The Man from Glengarry. Toronto: McClelland.

Conner, Ralph. (1909). The Foreigner: A Tale of Saskatchewan. Toronto:

Westminster Co.

Jiménez, Marina. (2007. January 12). How Canadian Are You? The Globe and Mail, p. Al.

MacLennan, Hugh. (1941). Barometer Rising. Toronto: McClelland.

Viswanathan, Gauri. (1989). Masks of Conquest: Literary Study and British Rule in India. London: Faber and Faber. 